\section{Research Square \\ Preprints are preliminary reports that have not undergone peer review They should not be considered conclusive, used to inform clinical practice, or referenced by the media as validated information.}

\title{
Contribution of IL9, IL2RA and IL2RB genetic polymorphisms in coronary heart disease in Chinese Han population
}

\author{
Xianghong Chen \\ The Second Affiliated Hospital of Hainan Medical University \\ Xingfan Wang \\ The Second Affiliated Hospital of Hainan Medical University \\ Zaozhang q Zhang \\ The second Affiliated Hospital of Hainan Medical University \\ Yuewu Chen \\ The Second Affiliated Hospital of Hainan Medical University \\ Chao Wang ( $\sim$ wangchao201901@sina.com) \\ The Second Affiliated Hospital of Hainan Medical Universiy https://orcid.org/0000-0001-5632-9778
}

\section{Research article}

Keywords:

Posted Date: December 9th, 2019

DOI: https://doi.org/10.21203/rs.2.18401/v1

License: (c) (i) This work is licensed under a Creative Commons Attribution 4.0 International License. Read Full License 


\section{Abstract}

Background: Coronary heart disease (CHD) is one of the leading causes of disability and death worldwide. In the pathogenesis of CHD, inflammatory cytokines take an essential part. This study was designed to detect the potential association between IL-9, IL-2RA and IL-2RB variants and CHD in Chinese Han population. Methods: This case-control study conducted $499 \mathrm{CHD}$ patients and 496 healthy controls. Seven selected SNPs were genotyped to investigate the possible association between the polymorphisms and the CHD risk. The interaction of SNP-SNP in the CHD risk was analyzed by Multifactor dimensionality reduction (MDR). Results: We observed an association between IL-9 rs55692658 (OR = $1.72, p=0.003$ ) and the increased CHD risk. The stratification analysis by age indicated that no matter participants who were older or younger than 61 years, IL-9 rs55692658 and IL-2RB rs 1573673 contributed to the CHD susceptibility significantly ( $<<0.05$, respectively). IL-9 rs55692658 showed an increasing-risk effect $(\mathrm{OR}=2.32, \mathrm{p}=0.003)$, while IL-2RA rs12722498 was correlated with the decreased susceptibility of CHD (OR = $0.54, p=0.033)$ in female. Furthermore, IL-2RA rs12569923 was related to the diabetes risk in the CHD patients (OR = 1.50, $p=0.028)$. MDR analysis revealed a positive interaction between the SNPs. Conclusion: The present study firstly demonstrated that IL-9 rs55692658 $1 \mathrm{IL}-2 \mathrm{RA}$ rs12569923, rs12722498 and IL-2RB rs3218264 polymorphisms might be related to CHD. The results required further validation by larger studies.

\section{Introduction}

Coronary heart disease (CHD), also known as coronary artery disease (CAD), is one of the leading causes of death worldwide. The disease is characterized by formation of arterial plaques which are mainly comprised of lipids, calcium and inflammatory cells(1) The pathogenesis of CHD is thought to be associated with multifactor, including atherosclerosis, obesity, hypertension, diabetes and smoking habits(2, 3). It was reported that inflammatory factors involving cytokines take an essential part in the progression of atherosclerosis, which eventually leads to $\mathrm{CHD}(4,5)$. Although researches in CHD have been ongoing in the latest years, the specific mechanism remains to be further clarified. Notably, genetic and environmental factors are widely considered to play crucial role in the etiology of CHD, especially the genetic factors which are key to an individual's susceptibility to $\mathrm{CHD}$, accounting for $30-60 \%$ of inter-individual variation in the risk of $\mathrm{CHD}(6,7)$.

Interleukin-9 (IL-9) is a pleiotropic cytokine, and its gene is located on 5q31.1(8). Previous studies revealed that serum IL-9 level was significant higher in patients with atherosclerosis or $\operatorname{CHD}(9,10)$. However, there were not any relative studies to research on the genetic effects of IL-9 with CHD. Additionally, Interleukin-2 (IL-2) was known as a T-cell growth factor when it was discovered in 1976 (11). The high affinity IL-2 receptor (IL$2 \mathrm{R}$ ) is a heterotrimer consisting of the a chain (IL-2RA, CD25), the $\beta$ chain (IL-2RB, CD122) and the common cytokine receptor $\gamma$ chain ( $\gamma c, C D 132$ ) (12). The previous studies indicated that IL-2, IL-2RA or IL-2RB genes caused muti-organ inflammation in both mice and human (13, 14). Importantly, IL-2RA and IL-2RB play crucial role in the development of CHD mainly through the combination with IL-2(15-17). It was reported that the gene variants in IL-2 were contributed the susceptibility to the CHD risk(18). However, it had little research to explore the IL-2R with CHD risk.

Therefore, in this study, we will conduct a case-control study to identify the association between CHD susceptibility and seven SNPs in the IL-9, IL2RA and IL-2RB in the Chinese Han population. The study aims to identify a positive finding for the early prevention of CHD.

\section{Materials And Methods}

\section{Study participants}

This hospital-based case-control study was performed with 499 CHD patients and 496 healthy controls randomly recruited from the Second Affiliated Hospital of Hainan Medical University. All of the participants were genetically unrelated Chinese Han adults. The patients were diagnosed with CHD based on the coronary angiography or the criteria of typical clinical symptom, elevation of cardiac enzymes, and representative set of electrocardiogram(ECG) (19). The cases with severe anto-immunity disease such as systemic lupus erythematosus, inflammatory bowel disease, or Graves' disease were excluded. For controls, the healthy adults without any kinds of cardiovascular disease or relative medical history were recruited from the health checkup of the same hospital at the same period. We designed this protocol in compliance with the the Ethics Committee of the Second Affiliated Hospital of Hainan Medical University and the guidelines of the Declaration of Helsinki. All participants were provided and signed up the written informed consent.

\section{Selection and genotyping of SNPs}

We identified three single nucleotide polymorphisms (SNPS) in IL-2RA, three SNPs in $I L-2 R B$ and one in $I L-9$ with a minor allele frequency (MAF) > 0.05 in Chinese Han population from NCBI dbSNP database (http://www.ncbi.nlm.nih.gov/projects/SNP) and the 1000 Genomes Projects (http://www.internationalgenome.org/). Fasting peripheral blood of all participants were collected in anticoagulant tubes and stored at $-80^{\circ} \mathrm{C}$. The whole blood genomic DNA extraction kit (GoldMag Co. Ltd, China) was used to extract DNA in accordance with manufacture's protocol, and the DNA content was measured by spectrometry (NanoDrop 2000 spectrophotometer, Thermo Scientific, USA). Agena MassARRAY Assay Design Software (version 3.0, Agena Bioscience, USA) was used to design multiplexed SNP MassEXTEND assay. And Agena MassARRAY RS100 was used to detect SNP genotyping $(20,21)$. Data were analyzed with Agena Typer Software (version 4.0, Agena Bioscience, USA). 


\section{Bioinformatics analysis}

Online softwares, HaploReg v4.1 (https ://pubsbroad institute.org/mamma Is/haploreg/haploreg.php) and SNP info Web Server (https://snpin fo.niehs.nih.gov/snpinfo/index.html), took essential part in predicting the possible functional effects on these candidate SNPs.

\section{Statistical analysis}

SPSS software (version 20.0) was used for data analysis. The independent sample t-test or $\chi^{2}$ test was used to examine the differences of basic parameters between the cases and controls. Hardy-Weinberg equilibrium (HWE) was tested by $\chi^{2}$ test for each SNP selected in this study. The CHD risk associated with genotyping was estimated by odds ratios (ORs) with $95 \%$ confidence intervals (Cls) for five different genetic models.

Multifactor dimensionality reduction (MDR) (version3.0.2) was performed to analyze the interactions between SNP and SNP in the CHD risk (22). The difference in clinical characteristics among different genotypes was analyzed using the one-way analysis and ANOVA test. For all test, a twotailed $p$-value $<0.05$ was considered statistically significant.

\section{Results}

\section{Basic characteristic of the participants}

The current study was included 499 CHD patients (319 males and 180 females) and 496 healthy controls (320 males and 273 females). The mean age of cases and controls were $61.34 \pm 11.70$ and $61.29 \pm 8.94$, respectively. Demographic and clinical characteristics were listed in Table 1 , including age, gender, total cholesterol (TC), triglyceride (TG), high-density lipoprotein (HDL), low-density lipoprotein (LDL), platelet (PLT), plateletcrit (PCT), white blood cells (WBC), red blood cells (RBC), hemoglobin (HGB) and uric acid (UA). To examined the association in subgroup of $\mathrm{CHD}$ with diabetes or hypertension, the group of $\mathrm{CHD}$ patients were divided into four groups based on the presence or absence of hypertension or diabetes (CHD patients with diabetes or non-diabetes, CHD patients with hypertension or non-hypertension). And then we could observe that there were $59 \%$ CHD patients who were along with hypertension, while $20 \%$ CHD patients had diabetes.

\section{Association of genetic polymorphism with the CHD risk}

Basic information of the selected SNPs was presented in Table 2. All of genetic polymorphisms were complied with a Hardy-Weinberg equilibrium $(p>0.05)$. Significantly in Table 3, majority of the genetic model in $/ L-9$ (rs55692658) presented the increased risk with CHD (A vs G, OR $=1.72$, $95 \% \mathrm{Cl}=1.20-2.48, p=0.003 ; \mathrm{GA}$ vs AA, OR = 1.66, 95\% Cl = 1.13-2.42, $p=0.010 ; \mathrm{GG}-\mathrm{GA}$ vs AA, OR = 1.72, 95\% Cl = 1.17-2.51, $p=0.006 ; \mathrm{Log}$ additive, $\mathrm{OR}=1.75,95 \% \mathrm{Cl}=1.20-2.53, p=0.003)$. However, the SNPs in $I L-2 R A$ and $I L-2 R B$ showed no statistical significance with $\mathrm{CHD}$ risk (Supplementary Table 1).

\section{Stratification analysis of SNPs with the CHD risk}

Then we did stratified analysis of SNPs with CHD risk (Table 4). The results indicated that no matter in participants who were $>61$ years or $\leq 61$ years, IL-9 rs55692658 and IL-2RB rs3218264 were significantly associated with the increased risk of CHD (In participants > 61 years old, IL-9 rs55692658: $\mathrm{G}$ vs A, OR $=1.65,95 \% \mathrm{Cl}=1.03-2.65, p=0.037, \mathrm{GG}-\mathrm{GA}$ vs $\mathrm{AA}, \mathrm{OR}=1.68,95 \% \mathrm{Cl}=1.01-2.81, p=0.049, \mathrm{Log}$-additive, OR $=1.73,95 \%$ $\mathrm{Cl}=1.05-2.83, p=0.030 ; \mathrm{IL}-2 \mathrm{RB}$ rs3218264: $\mathrm{AG}$ vs GG, OR = 1.61,95\% Cl=1.03-2.51, $p=0.037, \mathrm{AA}-\mathrm{AG}$ vs GG, OR $=1.59,95 \% \mathrm{Cl}=1.05-2.42, p=$ 0.030; In participants $\leq 61$ years old, IL-9 rs55692658: $\mathrm{G}$ vs $\mathrm{A}, \mathrm{OR}=1.90,95 \% \mathrm{Cl}=1.07-3.39, p=0.027, \mathrm{GG}-\mathrm{GA}$ vs $\mathrm{AA}, \mathrm{OR}=2.00,95 \% \mathrm{Cl}=1.10-$ 3.66, $p=0.024$, Log-additive, $\mathrm{OR}=2.00,95 \% \mathrm{Cl}=1.10-3.66, p=0.024 ; \mathrm{IL}-2 R B$ rs3218264: $\mathrm{AG}$ vs GG, OR=1.59, 95\% Cl = 1.03-2.46, $p=0.036, \mathrm{AG}-$ AA vs GG, OR $=1.51,95 \% \mathrm{Cl}=1.01-2.28, p=0.046)$ However, three selected SNPs in IL-2RA and another two SNPs in $I L-2 R B$ showed susceptibility to $\mathrm{CHD}$ risk with no statistical significance (Supplementary table 2).

By the stratification of gender shown in Table 4, we observed that $/ L-9$ rs55692658 was significantly correlated with the $\mathrm{CHD}$ risk (G vs $\mathrm{A}$, OR = $2.32,95 \% \mathrm{Cl}=1.30-4.13, p=0.003, \mathrm{GA}$ vs AA, OR $=2.22,95 \% \mathrm{Cl}=1.21-4.09, p=0.010, \mathrm{GG}-\mathrm{GA}$ vs $\mathrm{AA}, \mathrm{OR}=2.35,95 \% \mathrm{Cl}=1.28-4.30, p=0.006, \mathrm{Log}$ additive, $\mathrm{OR}=2.36,95 \% \mathrm{Cl}=1.31-4.25, p=0.004)$. Nevertheless, IL-2RA rs 12722498 presented a significantly decreasing-risk effect in female (G vs $\mathrm{A}, \mathrm{OR}=0.54,95 \% \mathrm{Cl}=0.30-0.96, p=0.033, \mathrm{GA}$ vs $\mathrm{AA}, \mathrm{OR}=0.52,95 \% \mathrm{Cl}=0.28-0.97, p=0.041, \mathrm{GG}-\mathrm{GA}$ vs $\mathrm{AA}, \mathrm{OR}=0.51,95 \% \mathrm{Cl}=0.28-0.95, p=$ 0.033 , Log-additive, $\mathrm{OR}=0.54,95 \% \mathrm{Cl}=0.30-0.96, p=0.035)$. On contrary, there were not any significant association between rs791588 and rs12569923 in IL-2RA, and three selected SNPs in IL-2RB and CHD risk (Supplementary table 3).

\section{Association with hypertension and diabetes}

To evaluate the association in subgroups of CHD with diabetes or hypertension, a total of $499 \mathrm{CHD}$ patients was divided into four groups according to presenting or absenting hypertension or diabetes, respectively. The results shown in Table 5 revealed that $I L-2 R A$ rs 12569923 presented the increased risk with diabetes in $\mathrm{CHD}$ patients ( $\mathrm{G}$ vs C, OR $=1.50,95 \% \mathrm{Cl}=1.04-2.17, p=0.028 ; \mathrm{GG}$ vs $\mathrm{CC}, \mathrm{OR}=2.70,95 \% \mathrm{Cl}=1.21$ $6.04, p=0.015$; GG vs GG-GC, OR = 2.59, 95\% Cl=1.18-5.69, $p=0.018$; Log-additive, $\mathrm{OR}=1.43,95 \% \mathrm{Cl}=1.01-2.02, p=0.044)$. On the contrary, all of the SNPs selected in this study were not significantly associated with hypertension in the CHD patients (Supplementary table 3). 


\section{Haplotype analysis with the risk of CHD}

Furthermore, we researched the linkage disequilibrium (LD) and haplotype analyses of the IL-2RA polymorphisms. The reconstructed LD plot was presented in Supplementary Figure 1, and the LD block was comprised of two SNPs including $/ L-2 R A$ rs 12569923 and rs791588. The frequencies distribution of haplotypes in the case and control groups were shown in Supplementary Table 4. However, there was no significant association between haplotype and the risk of CHD.

\section{SNP-SNP interactions}

We used MDR analysis to assess the effect of SNP-SNP interaction among seven selected SNPs in IL-9, IL-2RA and IL-2RB (Table 6). In total, we found a three-locus mode including rs 12569923 in $I L-2 R A$, rs3218264 in IL-2RB and rs55692658 in $I L-9$ was the best model (cross-validation consistency $=9 / 10$, testing balanced accuracy $=0.539, p=0.002$ ). Obviously, there were interactions between locus and locus presented in a dendrogram and the Fruchterman-Reingold in Figure 1 ( $A$ and $B$, respectively).

\section{Genotypes and clinical characteristics}

Additionally, we chose three SNPs in $I L-9, I L-2 R A, I L-2 R B$ which presented the most significant association with the CHD risk according to the above studies to detected the relationship between different genotypes of these SNPs and clinical characteristics of patients, including total cholesterol (TC), triglyceride (TG), high-density lipoprotein (HDL), low-density lipoprotein (LDL), platelet (PLT), plateletcrit (PCT), white blood cells (WBC), red blood cells (RBC), hemoglobin (HGB), uric acid (UA). As shown in Table 7, there was no significant association between IL-9 rs55692658 and IL-2RA rs12569923 genotype polymorphisms and the clinical parameters mentioned above $(p>0.05)$. However, the AA genotype $(1.61 \pm 0.67 \mathrm{mmol} / \mathrm{L})$ of $/ \mathrm{L}-2 R B \mathrm{rs} 3218264$ were higher TG level than AG genotype $(1.43 \pm 0.60 \mathrm{mmol} / \mathrm{L})$ and GG genotype $(1.40 \pm 0.64 \mathrm{mmol} / \mathrm{L})$ $(p=0.035)$.

\section{Discussion}

$\mathrm{CHD}$ is considered to be a multifactorial disease, characterized by a chronic inflammatory process occurring primarily at the atherosclerotic plaque (23). Although the etiology of CHD remains to be further clarified, the genetic and environmental factors are regarded as important aspects in the progression of this disease. Previous studies have reported that serum interleukins level was correlated with the development of $\mathrm{CHD}$, including IL9 and IL-2 $(23,24)$. As a kind of key inflammatory factors, interleukins have been the center of attention up to now. Gradually, the multiple gene polymorphisms in interleukins with CHD risk began to be explore $(25,26)$, but little have reported about IL-9, IL-2RA and IL-2RB.

Therefore, we designed this case-control study to investigate the association between the SNPs in IL-9, IL-2A, IL-2RB and the susceptibility to CHD. The results revealed that there was a strong relationship of IL-9 rs55692658 with CHD risk. Furthermore, the stratification analysis by age showed that IL-9 rs55692658 and IL-2RB rs1573673 were significantly correlated with the increased risk of CHD without age relevant. For the subgroup of gender, we observed that IL-9 rs55692658 presented an increasing-risk effect, while IL-2RA rs12722498 was correlated with the decreased susceptibility to CHD in female. Moreover, IL-2RA rs12569923 was associated with the risk of diabetes in CHD patients. Since CHD represented a complex disease influenced by an interplay between genetic and environmental factors, SNP-SNP interaction studies might help identify the risk factors for CHD. Accordingly, we did MDR analysis to detected the potential SNP-SNP interactions in the selected SNPs. The results indicated that there was a strong interaction between IL-9 rs55692658, IL-2RA rs12569923 and IL-2RB rs3218264 regarding susceptibility to CHD. To our knowledge, this is the firstly to demonstrated the relationships between these SNPs in IL-9, IL-2RA, IL-2RB and the risk of CHD.

IL-9 gene was located on the long arm of chromosome 5. And IL-9 is specifically secreted not only by the eponymous Th9 cells, but also by a smaller amount by activated Th2 cells, Th17 cells, and regulatory T cells (27). Recently, few studies have revealed that IL-9 might mediate inflammatory cell infiltration into atherosclerotic lesions and might also play an important role in the atherosclerotic process (10, 28). According to these studies, we hypothesized that IL-9 SNPs might be related to CHD risk. In current study, we found that IL-9 rs55692658 was significant associated with an increased risk effect on CHD. Furthermore, gender and age were well-known risk factors in the prevalence of CHD (29). Therefore, we evaluated the correlation between the SNPs of IL-9 and CHD risk in different subgroups. Furthermore, by the stratification analysis with age and gender, we found that IL-9 rs55692658 contributed the susceptibility to CHD risk without age relevant. However, its increasing risk effect was significantly correlated with female.

Besides, serum levels of IL-2 was reported the relationship with CHD $(16,30)$. IL-2, a type 1 four a-helical bundle cytokine, was produced primarily by CD4 + T cells following their activation by antigen (31). IL-2R, especially the IL-2RA and IL-2RB which had high affinity to the IL-2, was obviously detected an increased serum level compared with the healthy controls according to the previous studies (31). Nevertheless, in the current study, we found that there was not any significant association between the selected SNPs in neither IL-2RA nor IL-2RB and the CHD risk. Thus, we did a further stratification analysis by age and gender. The results indicated that in patients who were at age $\leq 61$, IL-2RB rs3218264 presented significantly increased risk effect on CHD. And in the subgroup of gender, it was revealed that IL-2RA rs 12722498 was showed the decreased contribution to CHD susceptibility. The previous study had reported that CHD was associated with diabetes (32). Additionally, the morbidity and 
mortality of CHD were related to degrees of increased blood pressure $(33,34)$. These suggested that CHD had close relationship with hypertension and diabetes. Hence, we did stratification analysis of hypertension and diabetes in CHD patients. The results significantly indicated that IL-2RA rs12569923 contributed to diabetes risk for individuals with CHD patients.

There are also limitations in the current study. At first, the sample size was not big enough and the subjects are limited to Chinese Han population. Consequently, selection bias is inevitable due to this study was hospital-based design. Then, CHD is a multifactorial disease with many other risk factors. We could not completely eliminate the potential influence of all the factors on the development of CHD. Hence, further studies with larger and multifarious sample are necessary.

\section{Conclusion}

In summary, the current study was the first to report that IL-9 rs55692658 significantly contributed the susceptibility to CHD risk. Specially, IL-2RA rs12722498 and IL-9 rs55692658 have significant differences in stratification analysis of gender. These results suggest that rs55692658 of IL-9 may serve as new biomarkers for the risk of CHD.

\section{Declarations}

\section{Ethics approval and consent to participate}

This study strictly obeyed the World Medical Association Declaration of Helsinki, which was also approved by the Ethical Committee of the Second Affiliated Hospital of Hainan Medical University. Written informed consent was obtained from each study participant.

\section{Consent for publication}

Not applicable.

\section{Competing interests}

The authors declare that they have no competing interests.

\section{Funding}

Not applicable.

\section{Author Contributions}

XHC drafted the manuscript. XFW and ZZZ performed the DNA extraction and genotyping; YWC and XFW performed the data analysis; ZZZ and YWC performed the sample collection and information recording; XHC and CW conceived and supervised the study.

\section{Acknowledgements}

We are appreciated to all participants in this study. Furthermore, we are grateful to the clinicians and staff in the Second Affiliated Hospital of Hainan Medical University, as well as the contributors in this study.

\section{References}

1. Li H, Sun K, Zhao R, et al. (2018) Inflammatory biomarkers of coronary heart disease. Front Biosci (Schol Ed) 10: 185-196.

2. Mitrokhin V, Nikitin A, Brovkina O, et al. (2017) Association between interleukin-6/6R gene polymorphisms and coronary artery disease in Russian population: influence of interleukin-6/6R gene polymorphisms on inflammatory markers. J Inflamm Res 10: 151-160.

3. Jokinen E. (2015) Obesity and cardiovascular disease. MINERVA PEDIATR 67: 25-32.

4. Min X, Lu M, Tu S, et al. (2017) Serum Cytokine Profile in Relation to the Severity of Coronary Artery Disease. BIOMED RES INT $2017: 4013685$.

5. Mirhafez SR, Zarifian A, Ebrahimi M, et al. (2015) Relationship between serum cytokine and growth factor concentrations and coronary artery disease. CLIN BIOCHEM 48: 575-580.

6. Marenberg ME, Risch N, Berkman LF, Floderus B, de Faire U. (1994) Genetic susceptibility to death from coronary heart disease in a study of twins. N Engl J Med 330: 1041-1046.

7. Sjogren M, Almgren P, Melander O. (2019) Polygenetic risk for coronary artery disease increases hospitalization burden and mortality. Int J Cardiol Heart Vasc 24: 100391.

8. Rojas-Zuleta WG, Sanchez E. (2017) IL-9: Function, Sources, and Detection. Methods Mol Biol 1585: 21-35.

9. Min X, Lu M, Tu S, et al. (2017) Serum Cytokine Profile in Relation to the Severity of Coronary Artery Disease. BIOMED RES INT 2017: 4013685. 
10. Gregersen I, Skjelland M, Holm S, et al. (2013) Increased systemic and local interleukin 9 levels in patients with carotid and coronary atherosclerosis. PLOS ONE 8: e72769.

11. Morgan DA, Ruscetti FW, Gallo R. (1976) Selective in vitro growth of T lymphocytes from normal human bone marrows. SCIENCE 193: 10071008.

12. Ruyssen-Witrand A, Lukas C, Nigon D, et al. (2014) Association of IL-2RA and IL-2RB genes with erosive status in early rheumatoid arthritis patients (ESPOIR and RMP cohorts). JOINT BONE SPINE 81: 228-234.

13. Willerford DM, Chen J, Ferry JA, Davidson L, Ma A, Alt FW. (1995) Interleukin-2 receptor alpha chain regulates the size and content of the peripheral lymphoid compartment. IMMUNITY 3: 521-530.

14. Sharfe N, Dadi HK, Shahar M, Roifman CM. (1997) Human immune disorder arising from mutation of the alpha chain of the interleukin-2 receptor. Proc Natl Acad Sci U S A 94: 3168-3171.

15. Simon AD, Yazdani S, Wang W, Schwartz A, Rabbani LE. (2001) Elevated plasma levels of interleukin-2 and soluble IL-2 receptor in ischemic heart disease. CLIN CARDIOL 24: 253-256.

16. Sakamoto A, Ishizaka N, Saito K, et al. (2012) Serum levels of IgG4 and soluble interleukin-2 receptor in patients with coronary artery disease. CLIN CHIM ACTA 413: 577-581.

17. Wadwa RP, Kinney GL, Ogden L, et al. (2006) Soluble interleukin-2 receptor as a marker for progression of coronary artery calcification in type 1 diabetes. Int J Biochem Cell Bio/ 38: 996-1003.

18. Ding R, Gao W, Ostrodci DH, et al. (2013) Effect of interleukin-2 level and genetic variants on coronary artery disease. INFLAMMATION 36: 1225-1231.

19. Thygesen K, Alpert JS, Jaffe AS, Simoons ML, Chaitman BR, White HD. (2012) Third universal definition of myocardial infarction. Glob Heart 7: 275-295.

20. Hoffman TW, van Moorsel C, Borie R, Crestani B. (2018) Pulmonary phenotypes associated with genetic variation in telomere-related genes. CURR OPIN PULM MED 24: 269-280.

21. Lin Y, Xue Y, Huang X, et al. (2018) Association between interleukin-35 polymorphisms and coronary heart disease in the Chinese Zhuang population: a case-control study. Coron Artery Dis 29: 423-428.

22. Leem S, Park T. (2017) An empirical fuzzy multifactor dimensionality reduction method for detecting gene-gene interactions. BMC GENOMICS 18: 115.

23. Wu MY, Li CJ, Hou MF, Chu PY. (2017) New Insights into the Role of Inflammation in the Pathogenesis of Atherosclerosis. INT J MOL SCI 18.

24. Kirbis S, Breskvar UD, Sabovic M, Zupan I, Sinkovic A. (2010) Inflammation markers in patients with coronary artery disease--comparison of intracoronary and systemic levels. WIEN KLIN WOCHENSCHR 122 Suppl 2: 31-34.

25. Zhang T, Wang Z, Xiao W. (2017) A meta-analysis of interleukin-6 -572G>C polymorphism and coronary heart disease susceptibility. CARDIOL J 24: 107-110.

26. Sun W, Han Y, Yang S, et al. (2019) The Assessment of Interleukin-18 on the Risk of Coronary Heart Disease. MED CHEM.

27. Gerlach K, Weigmann B. (2019) The dichotomous function of interleukin-9 in cancer diseases. J Mol Med (Berl) 97: 1377-1383.

28. Zhang W, Tang T, Nie D, et al. (2015) IL-9 aggravates the development of atherosclerosis in ApoE-/- mice. CARDIOVASC RES 106: $453-464$.

29. Khamis RY, Ammari T, Mikhail GW. (2016) Gender differences in coronary heart disease. HEART 102: 1142-1149.

30. Rizos I, Tsiodras S, Rigopoulos AG, et al. (2007) Interleukin-2 serum levels variations in recent onset atrial fibrillation are related with cardioversion outcome. CYTOKINE 40: 157-164.

31. Liao W, Lin JX, Leonard WJ. (2011) IL-2 family cytokines: new insights into the complex roles of IL-2 as a broad regulator of T helper cell differentiation. CURR OPIN IMMUNOL 23: 598-604.

32. Vedin O, Hagstrom E, Ostlund O, et al. (2017) Associations between tooth loss and prognostic biomarkers and the risk for cardiovascular events in patients with stable coronary heart disease. INT J CARDIOL 245: 271-276.

33. Reunanen A, Takkunen H, Knekt P, Aromaa A. (1982) Hyperuricemia as a risk factor for cardiovascular mortality. Acta Med Scand Supp/668: 49-59.

34. Zhao XC, Yang SH, Yan YQ, et al. (2018) Identification of differential gene expression profile from peripheral blood cells of military pilots with hypertension by RNA sequencing analysis. BMC MED GENOMICS 11: 59.

\section{Tables}

Table 1 Characteristics of patients with CHD patients and healthy controls 


\begin{tabular}{|c|c|c|c|}
\hline \multirow[t]{2}{*}{ Characteristics } & \multirow{2}{*}{$\begin{array}{l}\text { Cases } \\
\mathrm{n}=499\end{array}$} & \multirow{2}{*}{$\begin{array}{l}\text { Controls } \\
\mathrm{n}=496\end{array}$} & \multirow[t]{2}{*}{$p$} \\
\hline & & & \\
\hline Age (years) mean $\pm \mathrm{SD}$ & $61.34 \pm 11.70$ & $61.29 \pm 8.94$ & 0.939 \\
\hline \multicolumn{4}{|l|}{ Age (years) } \\
\hline$\leq 61$ & $250(50.0 \%)$ & $223(55.0 \%)$ & \\
\hline a61 & $249(50.0 \%)$ & $273(45.0 \%)$ & \\
\hline \multicolumn{4}{|l|}{ Gender } \\
\hline Male & 319 (63.7\%) & 320 (64.5\%) & 0.795 \\
\hline Female & $180(36.3 \%)$ & $176(35.5 \%)$ & \\
\hline TC $(\mathrm{mmol} / \mathrm{L})$ & $4.09 \pm 1.14$ & $4.61 \pm 0.94$ & $<0.001$ \\
\hline TG (mmol/L) & $1.46 \pm 0.63$ & $1.52 \pm 0.68$ & 0.252 \\
\hline HDL (mmol/L) & $1.09 \pm 0.28$ & $1.08 \pm 0.27$ & 0.571 \\
\hline $\mathrm{LDL}(\mathrm{mmol} / \mathrm{L})$ & $1.92 \pm 0.88$ & $2.61 \pm 0.78$ & $<0.001$ \\
\hline $\operatorname{PLT}\left(10^{9} / \mathrm{L}\right)$ & $182.97 \pm 59.56$ & $210.33 \pm 53.30$ & $<0.001$ \\
\hline PCT (\%) & $0.02 \pm 0.11$ & $0.02 \pm 0.07$ & 0.878 \\
\hline WBC $\left(10^{9} / \mathrm{L}\right)$ & $7.52 \pm 3.03$ & $5.83 \pm 1.51$ & $<0.001$ \\
\hline $\operatorname{RBC}\left(10^{12} / \mathrm{L}\right)$ & $4.85 \pm 0.54$ & $4.72 \pm 0.71$ & 0.003 \\
\hline HGB $(g / L)$ & $130.58 \pm 29.82$ & $145.53 \pm 13.24$ & $<0.001$ \\
\hline Urea $(\mathrm{mmol} / \mathrm{L})$ & $5.52 \pm 1.74$ & $5.18 \pm 1.31$ & 0.031 \\
\hline $\mathrm{UA}(\mu \mathrm{mol} / \mathrm{L})$ & $286.88 \pm 72.50$ & $322.88 \pm 66.86$ & $<0.001$ \\
\hline Hypertension (yes/no) & $295 / 204$ & & \\
\hline Diabetes (yes / no) & $101 / 39$ & & \\
\hline
\end{tabular}

TC, total cholesterol; TG, triglyceride; HDL, high-density lipoprotein; LDL, low-density lipoprotein; PLT, platelet; PCT, plateletcrit; WBC, white blood cells; RBC, red blood cells; HGB, hemoglobin; UA, uric acid

Variables are presented as the mean \pm SD.

Bold values indicate significant difference $(p<0.05)$.

Table 2 Basic information and HWE about the selected SNPs

\begin{tabular}{|c|c|c|c|c|c|c|c|c|c|}
\hline \multirow[t]{2}{*}{ SNP ID } & \multirow[t]{2}{*}{ Genes } & \multirow{2}{*}{$\begin{array}{l}\text { Chr: } \\
\text { Position }\end{array}$} & \multirow[t]{2}{*}{ Role } & \multirow[t]{2}{*}{ Alleles(A/B) } & \multicolumn{2}{|l|}{ MAF } & \multirow{2}{*}{$\begin{array}{l}\text { p- } \\
\text { value } \\
\text { for } \\
\text { HWE }\end{array}$} & \multirow[t]{2}{*}{ Haploreg 4.1} & \multirow{2}{*}{$\begin{array}{l}\text { SNPinfo } \\
\text { web } \\
\text { server }\end{array}$} \\
\hline & & & & & Cases & Controls & & & \\
\hline rs55692658 & IL-9 & $\begin{array}{ll}5: \\
135895540\end{array}$ & intronic & $\mathrm{A} / \mathrm{G}$ & 0.082 & 0.049 & 0.623 & Enhancer histone marks & TFBS \\
\hline rs12569923 & $\begin{array}{l}\text { IL- } \\
\text { 2RA }\end{array}$ & $\begin{array}{l}\text { 10: } \\
6042690\end{array}$ & intronic & $\mathrm{C} / \mathrm{G}$ & 0.197 & 0.206 & 0.784 & Enhancer histone marks, Motifs changed & \\
\hline rs791588 & $\begin{array}{l}\text { IL- } \\
\text { 2RA }\end{array}$ & $\begin{array}{l}10: \\
6047379\end{array}$ & intronic & $\mathrm{G} / \mathrm{T}$ & 0.363 & 0.374 & 0.774 & Enhancer histone marks, Motifs changed & \\
\hline rs12722498 & $\begin{array}{l}\text { IL- } \\
\text { 2RA }\end{array}$ & $\begin{array}{l}10: \\
6053873\end{array}$ & intronic & $\mathrm{C} / \mathrm{T}$ & 0.079 & 0.088 & 0.405 & $\begin{array}{l}\text { Promoter histone marks, Enhancer histone marks, } \\
\text { DNAse, Proteins bound, Motifs changed }\end{array}$ & \\
\hline rs2281089 & $\begin{array}{l}\text { IL- } \\
2 \mathrm{RB}\end{array}$ & $\begin{array}{l}22: \\
37136132\end{array}$ & intronic & $\mathrm{A} / \mathrm{G}$ & 0.249 & 0.234 & 0.618 & Enhancer histone marks & \\
\hline rs3218264 & $\begin{array}{l}\text { IL- } \\
2 R B\end{array}$ & $\begin{array}{l}22: \\
37145958\end{array}$ & intronic & $\mathrm{C} / \mathrm{T}$ & 0.485 & 0.486 & 0.073 & $\begin{array}{l}\text { Promoter histone marks, Enhancer histone marks, } \\
\text { DNAse, Proteins bound, Motifs changed, Selected eQTL } \\
\text { hits }\end{array}$ & \\
\hline rs1573673 & $\begin{array}{l}\text { IL- } \\
2 \mathrm{RB}\end{array}$ & $\begin{array}{l}22: \\
37172630 \\
\end{array}$ & intronic & $\mathrm{C} / \mathrm{T}$ & 0.369 & 0.381 & 0.774 & $\begin{array}{l}\text { Enhancer histone marks, Motifs Changed, GRASP QTL } \\
\text { hits }\end{array}$ & \\
\hline
\end{tabular}


Table 3 Relationships between the SNPs of $I L-9$ and CHD risk

\begin{tabular}{|c|c|c|c|c|c|c|}
\hline \multirow[t]{2}{*}{ SNP ID } & \multirow[t]{2}{*}{ Model } & \multirow[t]{2}{*}{ Genotype } & \multirow[t]{2}{*}{ Case } & \multirow[t]{2}{*}{ Control } & \multicolumn{2}{|c|}{ Adjusted by age and gender } \\
\hline & & & & & OR $(95 \% \mathrm{CI})$ & $p$ \\
\hline IL-9 & Allele & G & 82 & 49 & 1.00 & \\
\hline \multirow[t]{9}{*}{ rs55692658 } & & A & 916 & 943 & $1.72(1.20-2.48)$ & 0.003 \\
\hline & Genotype & AA & 420 & 447 & 1.00 & \\
\hline & & GG & 3 & 0 & I & I \\
\hline & & GA & 76 & 49 & $1.66(1.13-2.42)$ & 0.010 \\
\hline & Dominant & AA & 420 & 447 & 1.00 & \\
\hline & & GG-GA & 82 & 132 & $1.72(1.17-2.51)$ & 0.006 \\
\hline & Recessive & GA-AA & 496 & 496 & 1.00 & - \\
\hline & & GG & 3 & 0 & - & \\
\hline & Log-additive & - & - & - & $1.75(1.20-2.53)$ & 0.003 \\
\hline
\end{tabular}

SNP, single nucleotide polymorphism; OR, odds ratio; 95\% CI, 95\% confidence interval.

$p$ values were calculated by logistic regression analysis with adjustments for age and gender.

"_" indicates Log-additive model; "I" indicates data missing.

Bold values indicate significant difference $(p<0.05)$.

Table 4 The SNPs of $I L-9, I L-2 R A$ or $I L-2 R B$ associated with CHD risk in the age and gender subgroup tests 


\begin{tabular}{|c|c|c|c|c|c|c|c|c|c|c|}
\hline $\begin{array}{c}\text { SNP ID } \\
\text { Age, years }\end{array}$ & Model & Allele/genotype & $\begin{array}{l}\text { Case } \\
>61 \\
\end{array}$ & Control & OR (95\% CI) & $p$ & $\begin{array}{l}\text { Case } \\
\leq 61 \\
\end{array}$ & Control & OR (95\% CI) & $p$ \\
\hline IL-9 & Allele & $\mathrm{A}$ & 453 & 515 & 1.00 & & 463 & 428 & 1.00 & \\
\hline \multirow[t]{9}{*}{ rs55692658 } & & G & 45 & 31 & $1.65(1.03-2.65)$ & 0.037 & 37 & 18 & $1.90(1.07-3.39)$ & 0.027 \\
\hline & Genotype & AA & 207 & 242 & 1.00 & & 213 & 205 & 1.00 & \\
\hline & & GG & 3 & 0 & l & l & 0 & 0 & I & l \\
\hline & & GA & 39 & 31 & $1.57(0.93-2.65)$ & 0.090 & 37 & 18 & - & - \\
\hline & Dominant & $\mathrm{AA}$ & 207 & 242 & 1.00 & & 213 & 205 & 1.00 & \\
\hline & & GG-GA & 42 & 31 & $1.68(1.01-2.81)$ & 0.049 & 37 & 18 & $2.00(1.10-3.66)$ & 0.024 \\
\hline & Recessive & GA-AA & 246 & 273 & 1.00 & & 250 & 223 & 1.00 & 0.477 \\
\hline & & GG & 3 & 0 & l & l & 0 & 0 & 1 & l \\
\hline & Log-additive & - & - & - & $1.73(1.05-2.83)$ & 0.030 & - & - & $2.00(1.10-3.66)$ & 0.024 \\
\hline IL-2RB & Allele & G & 237 & 283 & 1.00 & & 253 & 247 & 1.00 & \\
\hline \multirow[t]{9}{*}{ rs3218264 } & & A & 261 & 263 & $1.19(0.93-1.51)$ & 0.171 & 247 & 199 & $1.21(0.94-1.57)$ & 0.141 \\
\hline & Genotype & GG & 55 & 78 & 1.00 & & 60 & 73 & 1.00 & \\
\hline & & $\mathrm{AA}$ & 67 & 68 & $1.56(0.94-2.58)$ & 0.085 & 57 & 49 & $1.36(0.81-2.28)$ & 0.244 \\
\hline & & AG & 127 & 127 & $1.61(1.03-2.51)$ & 0.037 & 133 & 101 & $1.59(1.03-2.46)$ & 0.036 \\
\hline & Dominant & GG & 55 & 78 & 1.00 & & 60 & 73 & 1.00 & \\
\hline & & AA-AG & 194 & 195 & $1.59(1.05-2.42)$ & 0.030 & 190 & 150 & $1.51(1.01-2.28)$ & 0.046 \\
\hline & Recessive & AG-GG & 182 & 205 & 1.00 & & 193 & 174 & 1.00 & \\
\hline & & $\mathrm{AA}$ & 67 & 68 & $1.14(0.76-1.71)$ & 0.536 & 57 & 49 & $1.01(0.65-1.57)$ & 0.951 \\
\hline & Log-additive & - & - & - & $1.24(0.97-1.60)$ & 0.090 & - & - & $1.02(0.77-1.34)$ & 0.894 \\
\hline $\begin{array}{l}\text { SNP ID } \\
\text { Gender }\end{array}$ & Model & Allele/genotype & $\begin{array}{l}\text { Case } \\
\text { Male }\end{array}$ & Control & OR $(95 \%$ CI $)$ & $p$ & $\begin{array}{c}\text { Case } \\
\text { Female }\end{array}$ & Control & OR (95\% CI) & $p$ \\
\hline IL-9 & Allele & A & 596 & 609 & 1.00 & & 320 & 334 & 1.00 & \\
\hline \multirow[t]{9}{*}{ rs55692658 } & & G & 42 & 31 & $1.38(0.86-2.23)$ & 0.180 & 40 & 180 & $2.32(1.30-4.13)$ & 0.003 \\
\hline & Genotype & AA & 278 & 289 & 1.00 & & 142 & 158 & 1.00 & \\
\hline & & GG & 1 & 0 & 1 & I & 2 & 0 & 1 & I \\
\hline & & GA & 40 & 31 & $1.34(0.81-2.21)$ & 0.248 & 36 & 18 & $2.22(1.21-4.09)$ & 0.010 \\
\hline & Dominant & $\mathrm{AA}$ & 278 & 289 & 1.00 & & 142 & 158 & 1.00 & \\
\hline & & GG-GA & 41 & 31 & $1.37(0.84-2.26)$ & 0.210 & 38 & 18 & $2.35(1.28-4.30)$ & 0.006 \\
\hline & Recessive & GA-AA & 318 & 320 & 1.00 & & 178 & 176 & 1.00 & \\
\hline & & GG & 1 & 0 & l & l & 2 & 0 & 1 & I \\
\hline & Log-additive & - & - & - & $1.40(0.86-2.28)$ & 0.177 & - & - & $2.36(1.31-4.25)$ & 0.004 \\
\hline IL-2RA & Allele & $\mathrm{A}$ & 579 & 582 & 1.00 & & 340 & 312 & 1.00 & \\
\hline \multirow[t]{9}{*}{ rs12722498 } & & G & 59 & 52 & $1.14(0.77-1.69)$ & 0.509 & 20 & 34 & $0.54(0.30-0.96)$ & 0.033 \\
\hline & Genotype & $\mathrm{AA}$ & 262 & 268 & 1.00 & & 161 & 141 & 1.00 & \\
\hline & & GG & 2 & 3 & $0.68(0.11-4.10)$ & 0.674 & 1 & 2 & $0.41(0.04-4.67)$ & 0.473 \\
\hline & & GA & 55 & 46 & $1.22(0.80-1.88)$ & 0.353 & 18 & 30 & $0.52(0.28-0.97)$ & 0.041 \\
\hline & Dominant & AA & 262 & 268 & 1.00 & & 161 & 141 & 1.00 & \\
\hline & & GG-GA & 57 & 49 & $1.19(0.78-1.81)$ & 0.413 & 19 & 32 & $0.51(0.28-0.95)$ & 0.033 \\
\hline & Recessive & GA-AA & 317 & 314 & 1.00 & & 179 & 171 & 1.00 & \\
\hline & & GG & 2 & 3 & $0.66(0.11-3.97)$ & 0.648 & 18 & 30 & $0.46(0.04-5.22)$ & 0.534 \\
\hline & Log-additive & - & - & - & $1.14(0.77-1.69)$ & 0.508 & - & - & $0.54(0.30-0.96)$ & 0.035 \\
\hline
\end{tabular}

OR, odds ratio; 95\% CI, 95\% confidence interval.

$p$ values were calculated by $\chi^{2}$ test with adjustment for age and gender.

"-" indicates Log-additive model; "I" indicates data missing.

Bold values indicate significant difference $(p<0.05)$.

Table $5 \mathrm{~A}$ list of SNPs associated with $\mathrm{CHD}$ in the subgroup tests (hypertension vs. non-hypertension and diabetes vs. non-diabetes) 


\begin{tabular}{|c|c|c|c|c|c|c|c|c|c|c|}
\hline SNP ID & Model & Allele/genotype & Case & Control & OR (95\% CI) & $p$ & Case & Control & OR (95\% CI) & $p$ \\
\hline & & \multicolumn{5}{|c|}{ Hypertension (Yes vs. No) } & \multicolumn{4}{|c|}{ Diabetes (Yes vs. No) } \\
\hline \multirow{10}{*}{$\begin{array}{l}\text { IL-2RA } \\
\text { rs12569923 }\end{array}$} & Allele & C & 464 & 337 & 1.00 & & 151 & 650 & 1.00 & \\
\hline & & G & 126 & 71 & 1.29 (0.93-1.78) & 0.123 & 51 & 146 & $1.50(1.04-2.17)$ & 0.028 \\
\hline & Genotype & $\mathrm{CC}$ & 187 & 144 & 1.00 & & 61 & 270 & 1.00 & \\
\hline & & GG & 18 & 11 & $1.33(0.60-2.94)$ & 0.478 & 11 & 18 & $2.70(1.21-6.04)$ & 0.015 \\
\hline & & GC & 90 & 49 & $1.43(0.95-2.17)$ & 0.089 & 29 & 110 & $1.15(0.70-1.89)$ & 0.581 \\
\hline & Dominant & $\mathrm{CC}$ & 187 & 144 & 1.00 & & 61 & 270 & 1.00 & \\
\hline & & GG-GC & 47 & 32 & $1.42(0.96-2.09)$ & 0.079 & 40 & 128 & $1.37(0.87-2.15)$ & 0.177 \\
\hline & Recessive & GC-CC & 277 & 193 & 1.00 & & 90 & 380 & 1.00 & \\
\hline & & GG & 18 & 11 & $1.20(0.55-2.62)$ & 0.649 & 11 & 18 & $2.59(1.18-5.69)$ & 0.018 \\
\hline & Log-additive & - & - & - & $1.28(0.94-1.75)$ & 0.117 & - & - & $1.43(1.01-2.02)$ & 0.044 \\
\hline
\end{tabular}

SNP, single nucleotide polymorphism; CHD, coronary heart disease; OR, odds ratio; $95 \%$ CI, 95\% confidence interval $p$ values were calculated by $\chi^{2}$ test with adjustment for age and gender.

“_” indicates Log-additive model.

Bold values indicate significant difference $(p<0.05)$.

Table 6 MDR analysis of SNP-SNP interactions in relation to CHD risk.

\begin{tabular}{|c|c|c|c|c|c|c|}
\hline Model & Training Bal. Acc & Testing Bal. Acc & OR $(95 \% \mathrm{CI})$ & Testing $\chi^{2}$ value & $p$ value & CVC \\
\hline rs3218264 (IL-2RB) & 0.533 & 0.508 & $1.32(1.01-1.71)$ & 4.143 & 0.042 & $5 / 10$ \\
\hline rs3218264 (IL-2RB), rs55692658 (IL-9) & 0.551 & 0.539 & $1.52(1.16-1.98)$ & 9.384 & 0.002 & $9 / 10$ \\
\hline rs 12569923 (IL-2RA), rs3218264 (IL-2RB), rs55692658 (IL-9) & 0.571 & 0.517 & $1.81(1.37-2.38)$ & 18.063 & $<0.0001$ & $5 / 10$ \\
\hline
\end{tabular}

MDR, multifactor dimensionality reduction; Bal. Acc., balanced accuracy; CVC, cross-validation consistency; OR, odds ratio; 95\% CI, 95\% confidence interval.

$p$ values were calculated using $\chi^{2}$ tests. $p<0.05$ indicates statistical significance. 


\begin{tabular}{|c|c|c|c|c|c|c|c|c|c|c|c|c|}
\hline \multirow[t]{2}{*}{ Characteristics } & \multicolumn{4}{|c|}{ IL-9 rs55692658 } & \multicolumn{4}{|c|}{$I L-2 R A$ rs12569923 } & \multicolumn{4}{|c|}{$I L-2 R B$ rs3218264 } \\
\hline & $\mathbf{A A}$ & GA & GG & $p$ & $\mathrm{CC}$ & GC & GG & $p$ & AA & AG & GG & $p$ \\
\hline $\mathrm{TC}(\mathrm{mmol} / \mathrm{L})$ & $\begin{array}{l}4.10 \pm \\
1.17\end{array}$ & $\begin{array}{l}4.02 \pm \\
0.98\end{array}$ & $\begin{array}{l}3.85 \pm \\
0.21\end{array}$ & 0.832 & $\begin{array}{l}4.08 \pm \\
1.13\end{array}$ & $\begin{array}{l}4.17 \pm \\
1.14\end{array}$ & $\begin{array}{l}3.77 \pm \\
1.21\end{array}$ & 0.245 & $\begin{array}{l}4.19 \pm \\
1.12\end{array}$ & $\begin{array}{l}4.04 \pm \\
1.14\end{array}$ & $\begin{array}{l}4.10 \\
\pm 1.15\end{array}$ & 0.555 \\
\hline TG (mmol/L) & $\begin{array}{l}1.46 \pm \\
0.63\end{array}$ & $\begin{array}{l}1.52 \pm \\
0.65\end{array}$ & $\begin{array}{l}1.18 \pm \\
0.25\end{array}$ & 0.618 & $\begin{array}{l}1.48 \pm \\
0.63\end{array}$ & $\begin{array}{l}1.47 \pm \\
0.63\end{array}$ & $\begin{array}{l}1.27 \pm \\
0.59\end{array}$ & 0.262 & $\begin{array}{l}1.61 \pm \\
0.67\end{array}$ & $\begin{array}{l}1.43 \\
0.60\end{array}$ & $\begin{array}{l}1.40 \pm \\
0.64\end{array}$ & 0.035 \\
\hline HDL (mmol/L) & $\begin{array}{l}1.10 \pm \\
0.28\end{array}$ & $\begin{array}{l}1.08 \pm \\
0.25\end{array}$ & $\begin{array}{l}1.15 \pm \\
0.21\end{array}$ & 0.886 & $\begin{array}{l}1.10 \pm \\
0.28\end{array}$ & $\begin{array}{l}1.11 \pm \\
0.29\end{array}$ & $\begin{array}{l}1.00 \pm \\
0.02\end{array}$ & 0.184 & $\begin{array}{l}1.10 \pm \\
0.30\end{array}$ & $\begin{array}{l}1.07 \pm \\
0.24\end{array}$ & $\begin{array}{l}1.13 \pm \\
0.32\end{array}$ & 0.142 \\
\hline LDL (mmol/L) & $\begin{array}{l}1.92 \pm \\
0.82\end{array}$ & $\begin{array}{l}1.94 \pm \\
1.18\end{array}$ & $\begin{array}{l}1.53 \pm \\
0.74\end{array}$ & 0.797 & $\begin{array}{l}1.90 \pm \\
0.89\end{array}$ & $\begin{array}{l}1.98 \pm \\
0.87\end{array}$ & $\begin{array}{l}1.84 \pm \\
0.87\end{array}$ & 0.616 & $\begin{array}{l}1.91 \pm \\
0.77\end{array}$ & $\begin{array}{l}1.94 \pm \\
0.97\end{array}$ & $\begin{array}{l}1.89 \pm \\
0.76\end{array}$ & 0.878 \\
\hline PLT $\left(10^{9} / \mathrm{L}\right)$ & $\begin{array}{l}183.55 \\
\pm \\
60.52\end{array}$ & $\begin{array}{l}179.79 \\
\pm \\
55.27\end{array}$ & $\begin{array}{l}185.00 \\
\pm \\
18.38\end{array}$ & 0.887 & $\begin{array}{l}180.96 \\
\pm \\
59.58\end{array}$ & $\begin{array}{l}174.29 \\
\pm \\
59.87\end{array}$ & $\begin{array}{l}174.29 \\
\pm \\
59.87\end{array}$ & 0.293 & $\begin{array}{l}189.67 \\
\pm \\
61.35\end{array}$ & $\begin{array}{l}182.66 \\
\pm \\
59.42\end{array}$ & $\begin{array}{l}177.99 \\
\pm \\
58.27\end{array}$ & 0.352 \\
\hline PCT (\%) & $\begin{array}{l}0.02 \pm \\
0.11\end{array}$ & $\begin{array}{l}0.02 \pm \\
0.08\end{array}$ & 1 & 0.927 & $\begin{array}{l}0.02 \pm \\
0.12\end{array}$ & $\begin{array}{l}0.29 \pm \\
0.78\end{array}$ & 1 & 0.806 & 1 & $\begin{array}{l}0.03 \pm \\
0.14\end{array}$ & $\begin{array}{l}0.02 \pm \\
0.07\end{array}$ & 0.419 \\
\hline WBC & $\begin{array}{l}7.57 \pm \\
3.13\end{array}$ & $\begin{array}{l}7.19 \pm \\
2.45\end{array}$ & $\begin{array}{l}8.59 \pm \\
0.83\end{array}$ & 0.553 & $\begin{array}{l}7.49 \pm \\
3.02\end{array}$ & $\begin{array}{l}7.66 \pm \\
3.15\end{array}$ & $\begin{array}{l}7.20 \pm \\
2.50\end{array}$ & 0.734 & $\begin{array}{l}7.79 \pm \\
3.06\end{array}$ & $\begin{array}{l}7.47 \pm \\
3.10\end{array}$ & $\begin{array}{l}7.40 \pm \\
2.87\end{array}$ & 0.598 \\
\hline $\mathrm{RBC}$ & $\begin{array}{l}4.73 \pm \\
0.66\end{array}$ & $\begin{array}{l}4.67 \pm \\
0.92\end{array}$ & $\begin{array}{l}3.89 \pm \\
0.16\end{array}$ & 0.194 & $\begin{array}{l}4.74 \pm \\
0.66\end{array}$ & $\begin{array}{l}4.71 \pm \\
0.70\end{array}$ & $\begin{array}{l}4.59 \pm \\
1.15\end{array}$ & 0.584 & $\begin{array}{l}4.82 \pm \\
0.63\end{array}$ & $\begin{array}{l}4.69 \pm \\
0.75\end{array}$ & $\begin{array}{l}4.69 \pm \\
0.68\end{array}$ & 0.284 \\
\hline HGB & $\begin{array}{l}131.16 \\
\pm \\
29.92\end{array}$ & $\begin{array}{l}129.06 \\
\pm \\
27.92\end{array}$ & $\begin{array}{l}93.00 \\
\pm \\
46.77\end{array}$ & 0.078 & $\begin{array}{l}130.33 \\
\pm \\
29.43\end{array}$ & $\begin{array}{l}131.80 \\
\pm \\
30.42\end{array}$ & $\begin{array}{l}127.38 \\
\pm \\
32.07\end{array}$ & 0.764 & $\begin{array}{l}127.0 \\
\pm \\
33.82\end{array}$ & $\begin{array}{l}131.9 \\
\pm \\
29.03\end{array}$ & $\begin{array}{l}130.8 \\
\pm \\
27.64\end{array}$ & 0.374 \\
\hline Urea & $\begin{array}{l}414 \pm \\
5.41\end{array}$ & $\begin{array}{l}72 \pm \\
5.39\end{array}$ & $\begin{array}{l}3 \pm \\
7.23\end{array}$ & 0.190 & $\begin{array}{l}5.34 \pm \\
1.63\end{array}$ & $\begin{array}{l}5.56 \pm \\
1.84\end{array}$ & $\begin{array}{l}5.59 \pm \\
2.36\end{array}$ & 0.421 & $\begin{array}{l}5.34 \pm \\
1.67\end{array}$ & $\begin{array}{l}5.37 \pm \\
1.68\end{array}$ & $\begin{array}{l}5.58 \\
\pm 1.90\end{array}$ & 0.479 \\
\hline $\begin{array}{l}\text { Uric acid } \\
(\mu \mathrm{mol} / \mathrm{L})\end{array}$ & $\begin{array}{l}287.0 \\
\pm \\
73.29 \\
\end{array}$ & $\begin{array}{l}287.89 \\
\pm \\
69.00 \\
\end{array}$ & $\begin{array}{l}247.67 \\
\pm \\
48.23 \\
\end{array}$ & 0.641 & $\begin{array}{l}288.96 \\
\pm \\
71.71 \\
\end{array}$ & $\begin{array}{l}282.91 \\
\pm \\
75.76 \\
\end{array}$ & $\begin{array}{l}281.85 \\
\pm \\
66.91 \\
\end{array}$ & 0.687 & $\begin{array}{l}77.3 \pm \\
14.70\end{array}$ & $\begin{array}{l}287.87 \\
\pm \\
72.59 \\
\end{array}$ & $\begin{array}{l}287.50 \\
\pm \\
74.32 \\
\end{array}$ & 0.934 \\
\hline
\end{tabular}

TC, total cholesterol; TG, triglyceride; HDL, high-density lipoprotein; LDL, low-density lipoprotein; PLT, platelet; PCT, plateletcrit; WBC, white blood cells; RBC, red blood cells; HGB, hemoglobin; UA, uric acid

"/" indicates data missing.

$p<0.05$ indicates statistical significance

\section{Figures}

A.

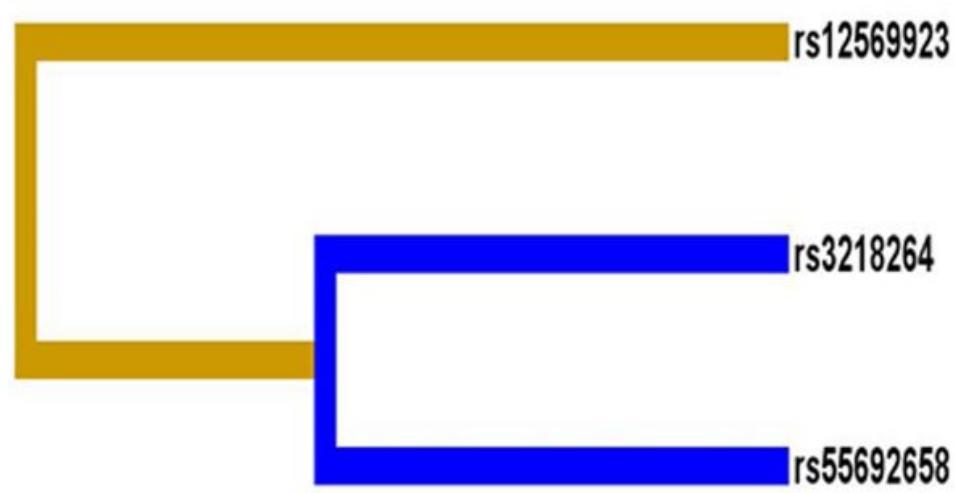

B.

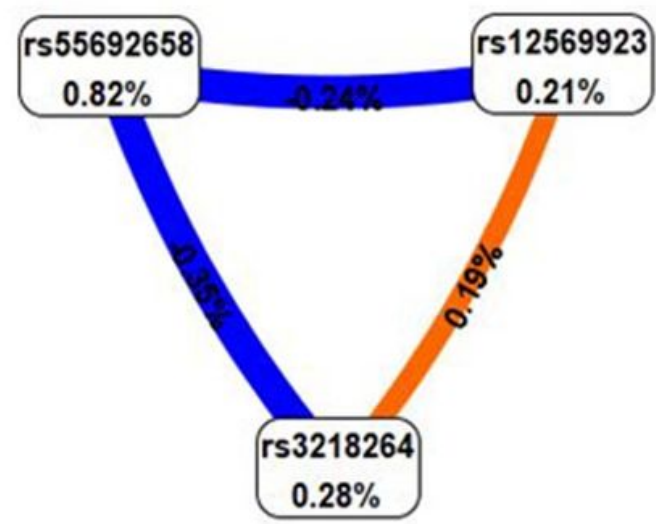

Figure 1 